\title{
A FIGURA DO BLOCO DE CONVENCIONALIDADE NAS DECISÕES PROFERIDAS PELA CORTE INTERAMERICANA DE DIREITOS
} HUMANOS

\section{THE FIGURE OF BLOCK OF CONVENCIONALITY IN THE DECISION RENDERED BY THE INTER-AMERICAN COURT OF HUMAN RIGHTS}

\author{
Vinicius de Almeida De Almeida Gonçalves \\ Formado em ciências jurídicas pelo Centro Universitário da Grande Dourados (UNIGRAN) e pós graduando lato sensu \\ em direitos humanos e cidadania pela Universidade Federal da Grande Dourados (Ufgd) \\ viniciusag@terra.com.br
}

\section{RESUMO}

0 presente artigo tem como objetivo realizar um estudo sobre a figura jurídica do bloco de convencionalidade, parâmetro para o controle de jurisdicional de convencionalidade, existente em decisões proferidas pela Corte Interamericana de Direitos Humanos. Para tanto, utilizou-se, para este artigo, uma revisão bibliográfica, tanto nacional como latino-americano, além de uma análise de jurisprudências, em especial, da Corte de Interamericana de Direitos Humanos que originaram o objeto de estudo. Com a análise desta figura jurídica se demonstrará a importância de desenvolver mais o pensamento da aplicação do bloco de convencionalidade para uma melhor efetivação de garantias e proteção aos direitos humanos em um sistema interamericano.

Palavras-chave: Bloco de convencionalidade; Controle de convencionalidade; Corte interamericana de direitos humanos; Tratados internacionais de direitos humanos.

\begin{abstract}
This article aims to conduct a study about the legal figure of block of convencionality, parameter to the jurisdictional control of convencionality, existent in decision rendered by the Inter-american Court of Human Rights. For this, was used, to this article, a literature review, nacional as latin-american, besides a jurisprudential analysis, in particular, of the InterAmerican Court Of Human Rights that originated the object of study. Whit the legal analysis of this figure will prove the importance of developing more thinking of applying block conventionality for better execution of guarantees and protection of human rights in an inter-America system.
\end{abstract}

Keywords: Block conventionality; Conventionality control; Inter-american Court of Human Rights; International Treaties on Huma Rights.

\section{SUMÁRIO}

INTRODUÇAO; 1 CONTROLE DE CONVENCIONALIDADE; 2 HISTÓRICO DO CONTROLE DE CONVENCIONALIDADE NA CORTE INTERAMERICANA DE DIREITOS HUMANOS; 3 A CRIAÇÃO DO BLOCO DE CONVENCIONALIDADE NAS DECISÕES DA CORTE INTERAMERICANA DE DIREITOS HUMANOS; 4 A APLICAÇÃO DO BLOCO DE CONVENCIONALIDADE DE ACORDO COM A CORTE INTERAMERICANA DE DIREITOS HUMANOS; CONCLUSÃO; REFERÊNCIAS. 


\section{INTRODUÇÃO}

Um dos novos pensamentos em proteção aos direitos humanos, tanto na esfera internacional como nacional, é a adoção do sistema de controle jurisdicional de convencionalidade das normas, ou seja, a atividade judicial de verificar a compatibilidade de uma lei interna em relação a um Tratado Internacional de Direitos Humanos.

Tal sistema foi adotado pela Corte Interamericana de Direitos Humanos em diversas decisões proferidas, atualmente, sendo um dos principais fundamentos para o respeito e aplicabilidade das mesmas decisões enunciadas por aquela Corte, tendo a cada sentença uma inovação ao sistema interamericano de proteção aos direitos humanos.

Entre tais decisões, citam-se três, a saber: Trabalhadores demitidos do Congresso vs. Peru, Ibsen Cárdenas e Ibsen Peña vs. Bolívia, Cabrera Garcia e Montiel Flores vs. México, a qual, na fundamentação dos votos elaborados para a decisão, surgiu a figura do bloco de convencionalidade para a resolução da questão de responsabilidade internacional proposta para apreciação da Corte.

Por bloco de convencionalidade, rapidamente, deve-se entender como a utilização de um corpus iuris de Direito Internacional dos Direitos Humanos como parâmetro para o exercício de um controle jurisdicional de convencionalidade.

O presente trabalho busca discutir sobre essa nova figura introduzida pela Corte Interamericana de Direitos Humanos, introduzida na fundamentação das decisões proferidas nos casos acima citados, para tanto, passa a tratar sobre a figura do controle de convencionalidade e seu surgimento dentro das decisões da Corte Interamericana, e, adiante, sobre a criação e análise da ideia de um bloco de convencionalidade dentro do sistema interamericano de proteção aos direitos humanos, e assim, adiante, analisar a possibilidade de sua aplicação no direito brasileiro.

\section{CONTROLE DE CONVENCIONALIDADE}

A fim de um melhor aproveitamento do tema deste trabalho, necessário se faz apresentar uma breve exposição sobre a figura do controle de convencionalidade, elemento atualmente de extrema importância na proteção aos direitos humanos. 
Em rápida síntese, controle de convencionalidade, significa o uso, como paradigma, de Tratados Internacionais de Direitos Humanos ratificados por um Estado para o controle jurisdicional de suas leis internas, ocorrendo esse controle tanto em um âmbito internacional e nacional.

Ensina Néstor Pedro Sagüés que o controle de convencionalidade, no âmbito do sistema interamericano de proteção dos direitos humanos, possui como fundamentos jurídicos: i) o princípio da boa-fé no cumprimento das obrigações internacionais, por parte dos Estadosmembros da Convenção Interamericana de Direitos Humanos, representado não apenas pelo cumprimento das normas previstas no Pacto de São José da Costa Rica, mas também as decisões proferidas pela Corte Interamericana de Direitos Humanos; ii) o princípio da efetividade dos Tratados Internacionais de Direitos Humanos, cujo a eficácia não pode ser diminuída por outras normas ou práticas dos Estados-membros, e; iii) a impossibilidade de um Estado invocar direito interno para justificar o inadimplemento de um tratado, conforme disciplina o artigo 27 da Convenção de Viena de $1969^{1}$.

Inicialmente, o controle de convencionalidade só será possível se um país aderir a Tratados Internacionais de Direitos Humanos, ou seja, se um Estado de Direito admite como uma das suas funções a luta e preservação dos Direitos Humanos.

Após a Segunda Guerra Mundial e suas consequências no mundo, notou-se o dever de fortalecer a proteção aos direitos do homem, tendo uma necessidade de responsabilização além do âmbito interno de um Estado. Assim, após esse período surgiu o Direito Internacional dos Direitos Humanos, representados pela elaboração de instrumentos internacionais que visam à proteção do ser humano. Porém, conforme aponta Flávia Piovesan, para a adoção desse novo ramo, do Direito Internacional dos Direitos Humanos, notou-se a importância da reconstrução de novas posturas em razão do indivíduo para o Estado: primeiramente pela relativização sobre o princípio da soberania do Estado, para uma efetiva proteção aos direitos humanos, já não há que se falar em soberania absoluta de um Estado, e, segundo, a cristalização do pensamento que o indivíduo deve ter seus direitos respeitos na órbita internacional ${ }^{2}$.

Tudo isso fortalece o que hoje se entende como "sistema normativo internacional de proteção aos direitos humanos”, representados pelos Tratados Internacionais de Direitos

\footnotetext{
${ }^{1}$ SAGÜÉS, Néstor Pedro. El "control de convencionalidad" em el sistema interamericano, y sus anticipios em el âmbito de los derechos econômicos-sociales. Concordancias y diferencias com el sistema europeo. Biblioteca jurídica virtual del instituto de investigaciones jurídicas de la UNAM. Disponível em: http://biblio.juridicas.unam.mx/libros/7/3063/16.pdf. Acesso em: 16 jul. 2013.

${ }^{2}$ PIOVESAN, Flávia. Temas de direitos humanos. 5. ed. São Paulo: Saraiva. 2.012.
} 
Humanos e os órgãos criados por estes, tais como, por exemplo, as Nações Unidas (em um âmbito global), e as Cortes Interamericana e Europeia de Direitos Humanos (em um âmbito regional).

Nesse desenvolver, diversos Estados passam a aderir aos Tratados Internacionais de Direitos Humanos no intuito de buscar garantias à proteção de tais direitos fundamentais aos seus indivíduos. Nessa evolução do Direito, como apontado acima, há a adoção de novas posturas e pensamentos jurídicos, dentre os quais, destaca-se o controle de convencionalidade.

Porém, ainda mesmo com o surgimento do Direito Internacional dos Direitos Humanos, demorou-se um pouco para a criação do pensamento sobre o controle de convencionalidade, e, para alguns países como o Brasil, ainda se discute sobre a adoção de um controle jurisdicional a mais dentro de um ordenamento jurídico interno, além dos já conhecidos controle de legalidade e controle de constitucionalidade, passando sobre o debate da hierarquia dos Tratados Internacionais de Direitos Humanos dentro de um sistema jurídico interno ${ }^{3}$.

Sobre essa divergência de pensamento acerca da incorporação dos Tratados Internacionais de Direitos Humanos em um ordenamento jurídico interno. Ainda a doutrina e jurisprudência brasileira se divide em atribuir a hierarquia de tais tratados dentro de uma ordem jurídica interna, podendo sintetizar em quatro pensamentos: a) os Tratados Internacionais de Direitos Humanos equiparados à lei ordinária; b) com natureza supralegal; c) com natureza constitucional; d) com natureza supraconstitucional.

Importante apontar que, para a majoritária doutrina latina americana ${ }^{4}$, entende-se que para uma correta aplicação do controle de convencionalidade, deve-se adotar o princípio da supremacia da Convenção Americana de Direitos Humanos. Para os adeptos a esta corrente, o princípio em comento se encontra explícito no artigo $2^{\circ}$ da Convenção Americana de Direitos Humanos, a qual se faz necessário transcrever:

Artigo $2^{\circ}$. Dever de adotar disposições de direito interno. Se o exercício dos direitos e liberdades mencionados no artigo 1 ainda não estiver garantido por disposições legislativas ou de outra natureza, os Estados-partes comprometem-se a adotar, de acordo com as suas normas constitucionais e com as disposições

\footnotetext{
${ }^{3}$ Sobre a rica discussão da hierarquia dos Tratados Internacionais sobre Direitos Humanos no ordenamento jurídico brasileiro dentro direito brasileiro, indica-se ao leitor: GOMES, Luiz Flávio. Controle de convencionalidade: Valerio Mazzuoli "versus" STF. Disponível em: http://ww3.lfg.com.br/public_html/article.php?story=20090615165108665\&mode=print. Acesso em: 01 ago. 2013.

${ }^{4}$ QUINCHE RAMÍREZ, Manuel Fernando. El control de constitucionalidad y el control de convencionalidad. Revista Centro de Estudios Políticos. Disponível em: http://www.centrodeestudiospoliticos.com/descargas/1.8.pdf. Acesso em: 16 jul. 2013.
} 
desta Convenção, as medidas legislativas ou de outra natureza que forem necessárias para tornar efetivos tais direitos e liberdades.

Tanto que este é o entendimento adotado pela jurisprudência da própria Corte Interamericana de Direitos Humanos: "El alcance de este control es tan fuerte, que la Corte Interamericana há llegado incluso a declarar la responsabilidad internacional, por la existencia de normas constitucionales contrarias a la Convención" ${ }^{5}$, como já feitas em algumas significativas decisões.

Adiante, para um correto controle de convencionalidade é preciso que os Tratados Internacionais de Direitos Humanos tenham, no mínimo, o status de norma constitucional dentro de um ordenamento jurídico interno, isso porque, em razão da força que os Direitos Humanos têm em decorrência do percurso histórico que o mundo sofreu, como apontado anteriormente, é necessário o respeito ao valor da dignidade da pessoa humana e efetivação dos direitos fundamentais do indivíduo, que é alcançado mediante a conciliação entre o Direito Interno com o Direito Internacional dos Direitos Humanos.

Neste presente trabalho, irá se adotar o pensamento de Valerio de Oliveira Mazzuoli em atribuir, de forma geral, o caráter de norma constitucional aos Tratados Internacionais de Direitos Humanos:

Por meio dessa solução que se acaba de expor, repita-se, não será a Constituição que excluirá a aplicação de um tratado ou vice-versa, mas ambas essas supernormas (Constituição e Tratados) é que irão se unir em prol da construção de um direito infraconstitucional compatível com ambas, sendo certo que a incompatibilidade desse mesmo direito infraconstitucional com apenas uma das supernormas já o invalida por completo. Com isto, possibilita-se a criação de um Estado Constitucional e Humanista de Direito que todo o direito doméstico guarde total compatibilidade tanto com a Constituição quanto com os tratados internacionais de direitos humanos ratificados pelo Estado, chegando-se, assim, a uma ordem jurídica interna perfeita, que tem no valor dos direitos humanos sua maior racionalidade, principiologia e sentido ${ }^{6}$.

Portanto, existe um duplo controle para averiguar se determinada norma infraconstitucional respeita a dignidade da pessoa humana. Esses controles devem ser exercidos

${ }^{5}$ QUINCHE RAMÍREZ, Manuel Fernando. El control de constitucionalidad y el control de convencionalidad. Revista Centro de Estudios Políticos. Disponível em: http://www.centrodeestudiospoliticos.com/descargas/1.8.pdf. Acesso em: 16 jul. 2013.

${ }^{6}$ MAZZUOLI, Valerio de Oliveira. 0 controle jurisdicional da convencionalidade das leis. Coleção direito e ciências afins: vol. 4. São Paulo: Editora Revista dos Tribunais. 2009. 
pelo Poder Judiciário ${ }^{7}$, a qual, ao mesmo tempo em que analisa a compatibilidade de uma lei infraconstitucional com a Carta Magna de um Estado - por meio de um controle de constitucionalidade - também deve realizar a análise de compatibilidade daquela mesma norma questionada em relação aos Tratados Internacionais de Direitos Humanos aderidos pelo Estado, por meio de um controle que será complementar e coadjuvante (jamais subsidiário) ao controle de constitucionalidade $^{8}$ - controle de convencionalidade - tem-se aqui a teoria da dupla compatibilidade vertical material das leis. Porém, logicamente, o controle de convencionalidade não pode se limitar a apenas os tribunais internos, estendendo-o aos tribunais internacionais, a qual, mais para frente, demonstrará que nestes últimos é que reside sua maior força vinculativa.

O controle jurisdicional de convencionalidade, assim como o controle de constitucionalidade, pode ocorrer tanto em sua forma difusa como em sua forma concentrada ou abstrata, uma das razões que justifica a semelhança entre as duas figuras de controle é em razão das características expostas acima, de complementação e coadjuvante, afinal, por mais que as normas utilizadas como parâmetros sejam diferentes, vale ressaltar a ideia das mesmas possuírem um mesmo valor normativo (ou, conforme exposto acima, um valor normativo superior), além de regularem a mesma norma inferior.

Portanto, quando se fala em um controle difuso de convencionalidade, afirma que é permitido a qualquer juiz ou tribunal atestar a devida compatibilidade de uma norma infraconstitucional com os Tratados Internacionais de Direitos Humanos aderidos pelo Estado, e, caso ocorra a incompatibilidade entre as normas hierarquicamente opostas, haverá o reconhecimento da inconvencionalidade ${ }^{9}$ e, portanto, a não aplicação da lei violadora no caso em concreto (efeito repressivo).

\footnotetext{
${ }^{7}$ Aponta Valerio de Oliveira Mazzuoli que já se utilizou, na doutrina brasileira, a expressão "controle de convencionalidade" como uma técnica legislativa em que o Parlamento de um Estado, deixa de adotar uma determinada lei que viole um Tratado Internacional de Direitos Humanos aderido pelo Estado, no intuito de afastar a responsabilidade internacional do Estado por ato do Poder Legislativo, tal pensamento foi apresentado por André de Carvalho Ramos. (MAZZUOLI, Valerio de Oliveira. O controle jurisdicional da convencionalidade das leis: o novo modelo de controle de produção normativa doméstica sob a ótica do “diálogo das fontes". Revista Argumenta. n. 15. 2.011. p; 77-114. Disponível em: http://seer.uenp.edu.br/index.php/argumenta/article/view/200/199. Acesso em: 12 jul. 2013).

${ }^{8}$ MAZZUOLI, Valerio de Oliveira. O controle jurisdicional da convencionalidade das leis. Coleção direito e ciências afins: vol. 4. São Paulo: Editora Revista dos Tribunais. 2009.

9 Também pode ser denominada como "anticonvencionalidade", como aponta Néstor Pedro Sagüés em: SAGÜÉS, Néstor Pedro. Obligaciones internacionales y control de convencionalidad. Estudios Constitucionales. ano 8. n. 1. 2010. p. 117-136. Disponível em: http://www.scielo.cl/scielo.php?pid=S0718-52002010000100005\&script=sci_arttext. Acesso em: 16 jul 2013.
} 
Jânia Maria Lopes Saldanha e Lucas Pacheco Vieira demonstram como seria realizado o controle difuso de convencionalidade na Justiça do Trabalho Brasileira, a qual, a título de ilustração, merece transcrever abaixo:

O controle difuso de convencionalidade das leis na Justiça do Trabalho deve ser realizado tendo como parâmetro as convenções da Organização Internacional do Trabalho, da seguinte forma: (a) faz-se o exame da compatibilidade de determinada convenção com a Constituição Federal; (b) verifica-se a compatibilidade das leis trabalhistas com as previsões da convenção; (c) constatada a contrariedade com o texto convencional, a respectiva lei trabalhista tem sua eficácia paralisada, sendo, então, aplicado o dispositivo da convenção ${ }^{10}$.

Respeitando a sistemática processual, o controle difuso de convencionalidade também produz efeitos inter pars, devendo ser arguido em vias de incidente processual (podendo ser arguido pelas partes como ex officio).

Ainda, em um controle concentrado de convencionalidade, dependerá do entendimento adotado em relação a incorporação dos Tratados Internacionais de Direitos Humanos, isso porque, caso adote-se a corrente de que aqueles tratados detém natureza de norma supraconstitucional, em relação ao Brasil, este deveria se submeter a um órgão supraconstitucional responsável pela proteção aos direitos humanos previstos em tratados internacionais, a qual seria, a Corte Interamericana de Direitos Humanos.

\begin{abstract}
Sem embargo, o controle de convencionalidade permite que a Corte Interamericana interprete e aplique a Convenção por meio de um exame de confrontação com o direito interno, podendo este ser uma lei, um ato administrativo, jurisprudência, práticas administrativas e judiciais, e até mesmo a Constituição. É possível, portanto, que um Estado-parte seja condenado pela Corte Interamericana de Direitos Humanos a revogar leis incompatíveis com a Convenção ou adaptar suas legislações através de reformas constitucionais para que se garanta a tutela de direitos humanos no âmbito do direito interno ${ }^{11}$.
\end{abstract}

Porém, como já apontado, neste trabalho se optou pelo entendimento de que os Tratados Internacionais de Direitos Humanos possuem status de norma constitucional, assim, ainda analisando pelo Brasil, o controle concentrado de convencionalidade não estaria restrito

\footnotetext{
${ }^{10}$ SALDANHA, Jânia Maria Lopes. VIEIRA, Lucas Pacheco. O controle difuso de convencionalidade das leis na justiça do trabalho com base nas convenções da organização internacional do trabalho: caminhos para a internacionalização do direito. Pensar - Revista de ciências jurídicas. v. 15. n. 2. 2.010. p. 457-485. Disponível em: http://ojs.unifor.br/index.php/rpen/article/view/2136/1734. Acesso em: 12 jul. 2013.

${ }_{11}^{11}$ GUERRA, Sidney. A proteção internacional dos direitos humanos no âmbito da corte interamericana e o controle de convencionalidade. Revista Nomos. v. 32.2. jul/dez. 2012. Disponível em: http://mdf.secrel.com.br/dmdocuments/Sidney\%20Guerra.pdf. Acesso em: 15 jul. 2013.
} 
apenas a Corte Interamericana de Direitos Humanas, mas também ao Supremo Tribunal Federal (guardião da Constituição Federal Brasileira), já que, cabe a este o controle concentrado de constitucionalidade.

Ainda, sobre o controle de convencionalidade realizado pela Corte Interamericana de Direitos Humanos, pode-se dizer também, que a Corte exerce seu papel consultivo em desenvolver os parâmetros que os juízes nacionais devem adotar em relação ao próprio controle de convencionalidade, conforme interpretação do artigo 64 do Pacto de São José da Costa Rica, isso porque, além do controle concentrado de convencionalidade sobre as leis de um Estadoparte, há também "el control sobre los hechos que sean materia de discusíon por los jueces internos em los asuntos de sus competencias"12.

Por fim, ainda aponta Néstor Pedro Sagüés ${ }^{13}$ a existência de um efeito positivo ou construtivo do controle de convencionalidade, a qual pode ser realizada por todo e qualquer juiz e tribunal, que deverão aplicar e fazer funcionar o direito local de acordo com as regras do Pacto de São José da Costa Rica, como também, a jurisprudência da Corte Interamericana de Direitos Humanos, harmonizando assim o direito interno e sua interpretação à normas da Convenção e jurisprudências da Corte.

\section{HISTÓRICO DO CONTROLE DE CONVENCIONALIDADE NA CORTE INTERAMERICANA DE DIREITOS HUMANOS}

É impossível discorrer sobre o controle de convencionalidade sem apresentar sua construção histórica, pois, a compreensão de suas generalidades se dá pelo desenvolver do pensamento nos Tribunais Internacionais de Direitos Humanos, a qual passasse a tratar.

A ideia de controle de convencionalidade é relevantemente nova no sistema jurídico mundial. Valerio de Oliveira Mazzuoli, aponta que tal pensamento tem origem francesa, por meio da decisão n. 74-54 DC, de 15 de janeiro de 1975, proferida pelo Conselho Constitucional Francês, a qual tinha reconhecido sua incompetência em analisar a convencionalidade

${ }^{12}$ QUINCHE RAMÍREZ, Manuel Fernando. El control de constitucionalidad y el control de convencionalidad. Revista Centro de Estudios Políticos. Disponível em: http://www.centrodeestudiospoliticos.com/descargas/1.8.pdf. Acesso em: 16 jul. 2013.

${ }^{13}$ SAGÜÉS, Néstor Pedro. El "control de convencionalidad" em el sistema interamericano, y sus anticipios em el âmbito de los derechos econômicos-sociales. Concordancias y diferencias com el sistema europeo. Biblioteca jurídica virtual del instituto de investigaciones jurídicas de la UNAM. Disponível em: http://biblio.juridicas.unam.mx/libros/7/3063/16.pdf. Acesso em: 16 jul. 2013. 
preventiva das leis, ou seja, a compatibilidade entre as leis francesas com os tratados ratificados pela França, por não se tratar, precisamente, de um controle de constitucionalidade ${ }^{14}$.

Ainda sobre a origem do pensamento do controle de convencionalidade pelo Conselho Constitucional Francês, a título de curiosidade, cita-se André de Carvalho Ramos:

Esse controle nacional foi consagrado na França em 1975 (decisão sobre a lei de interrupção voluntária da gravidez), quando o Conselho Constitucional, tendo em vista o artigo 55 da Constituição francesa sobre o estatuto supralegal dos tratados, decidiu que não the cabia a análise da compatibilidade de lei com tratado internacional. Essa missão deve ser efetuada pelos juízos ordinários, sob o controle da Corte de Cassação e do Conselho de Estado ${ }^{15}$.

O pensamento do controle de convencionalidade passou-se a ser utilizado, em grande frequência, pelos tribunais protetores dos direitos humanos, em especial pela Corte Interamericana de Direitos Humanos e a Corte Europeia de Direitos Humanos, sendo que a construção do pensamento que atualmente se aplica sobre esse controle se dá pela série de casos submetidos à apreciação a tais Tribunais.

No âmbito da Corte Interamericana de Direitos Humanos, há quem afirma que a formação do pensamento sobre o controle de convencionalidade surgiu a partir de 1994 pela Corte Interamericana de Direitos Humanos, por meio de opiniões consultivas, em especial pela Opinião Consultiva OC-14/94 de 09 de dezembro de 1994, Responsabilidad Internacional por Expedición y Aplicación de Leyes Violatorias de la Convención (art. $1^{\circ}$ y $2^{\circ}$ Convención Americana sobre Derechos Humanos), a qual preveu:

50. A Corte concluí que a promulgação de uma lei manifestamente contrária as obrigações assumidas por um Estado ao ratificar ou aderir a Convenção, constitui uma violação desta e que, no caso em que essa violação afete direitos e liberdades protegidas de determinados indivíduos, gera a responsabilidade internacional para o Estado. ${ }^{16}$

\footnotetext{
${ }^{14}$ MAZZUOLI, Valerio de Oliveira. O controle jurisdicional da convencionalidade das leis. Coleção direito e ciências afins: vol. 4. São Paulo: Editora Revista dos Tribunais. 2009.

${ }^{15}$ RAMOS, André de Carvalho. Teoria geral dos direitos humanos na ordem internacional. 2. ed. São Paulo: Saraiva. 2012.

${ }^{16}$ QUINCHE RAMÍREZ, Manuel Fernando. El control de constitucionalidad y el control de convencionalidad. Revista Centro de Estudios Políticos. Disponível em: http://www.centrodeestudiospoliticos.com/descargas/1.8.pdf. Acesso em: 16 jul. 2013. Do original: "La corte concluye que la promulgación de uma ley manifiestamente contraria a las obligaciones asumidas por um Estado al ratificar o adherir a la Convención constituye una violación de esta y que, en el evento de que esa violacíon afecte derechos y libertades protegidos respecto de indivíduos determinados, genera responsabilidad internacional para el Estado".
} 
Todavia, é por meio de decisões em casos contenciosos que fortaleceu a evolução do controle de convencionalidade na Corte Interamericana, mais precisamente, iniciando, no caso $A$ Última Tentação de Cristo (Olmedo e outros) vs. Chile, em sentença proferida em 05 de fevereiro de 2001, a qual a Corte entendeu que a Constituição do Chile contrariava a Convenção Interamericana de Direitos Humanos, ao prever em seu texto constitucional censura televisiva, exigindo a reforma do Texto Constitucional daquele país.

87. No direito das gentes, uma norma convencional prescreve que um Estado que tenha ratificado um tratado de direitos humanos debe introducir em seu direito interno as modificações necessárias para asegurar o fiel cumprimento das obrigações assumidas. Esta norma é universalmente aceita, com respaldo jurisprudencial. A Convenção Americana estabelece a obrigação geral de cada Estado Parte de adequar seu direito interno às disposições da Convenção, para garantir os direitos por ela consagrados. Este deber geral do Estado Parte implica que as medidas de direito interno debe ser efetivas (principio do effet utile). Isto significa que o Estado há de adotar todas as medidas para que o estabelecido na Convenção seja efetivamente cumprido em seu ordenamento jurídico interno, tal como requer o artigo 2 da Convenção. Tais medidas só são eficazes quando o Estado ajusta suas ações com as normas de proteção da Convenção. ${ }^{17}$

O que se observa, na verdade, é a implementação do fundamento do respeito do Estado-parte às normas do Pacto de São José da Costa Rica, devendo o país respeitá-lo, repetindo a Opinião Consultiva OC-14/94 citada acima, fundamento este essencial para a formação de um controle concentrado de convencionalidade pela Corte.

Mais adiante, em 25 de novembro de 2003, foi proferida sentença no caso Myrna Mack Chang vs. Guatemala, em que tratou da responsabilização da Guatemala pela morte de Myrna Mack Chang, ativista social, em uma operação militar. No caso em tela, o juiz Sérgio García Ramirez, em voto singular, mencionou expressamente o controle de convencionalidade.

17 CORTE IDH. Caso “La Última Tentación de Cristo“ (Olmedo Bustos y otros) Vs. Chile. Fondo, Reparaciones y Costas. Sentencia de 5 de febrero de 2001. Serie C No. 73. Disponível em: http://www.corteidh.or.cr/docs/casos/articulos/Seriec_73_esp.pdf. Acesso em: 16 jul. 2013. Do original: "En el derecho de gentes, una norma consuetudinaria prescribe que un Estado que ha ratificado un tratado de derechos humanos debe introducir en su derecho interno las modificaciones necesarias para asegurar el fiel cumplimiento de las obligaciones asumidas. Esta norma es universalmente aceptada, con respaldo jurisprudencial. La Convención Americana establece la obligación general de cada Estado Parte de adecuar su derecho interno a las disposiciones de dicha Convención, para garantizar los derechos en ella consagrados. Este deber general del Estado Parte implica que las medidas de derecho interno han de ser efectivas (principio del effet utile). Esto significa que el Estado ha de adoptar todas las medidas para que lo establecido en la Convención sea efectivamente cumplido en su ordenamiento jurídico interno, tal como lo requiere el artículo 2 de la Convención. Dichas medidas sólo son efectivas cuando el Estado adapta su actuación a la normativa de protección de la Convención". 
27. Para os efeitos da Convenção Americana e do exercício da jurisprudencia contenciosa da Corte Interamericana, o Estado trata de contas, em forma integral, como um todo. Nest orden, a responsabilidade é global, preocupando o Estado em seu conjunto e não pode estar sujeita a divisão de atribuições, que tras o Direito interno. Não é possível sancionar internacionalmente o Estado, obrigar, forçar o Tribunal apenas um ou alguns de seus órgãos, entregar a estes a representação do Estado em julgamento - sem que essa representação repercute sobre o Estado e seu conjunto - e subtrair a outros a este regime convencional de responsabilidade, partindo suas atribuições fora do "controle de convencionalidade" que tras consigo a jurisdição da Corte Internacional. ${ }^{18}$

Neste mesmo sentido, em 07 de setembro de 2004, foi proferida sentença no caso Tibi vs. Equador, caso em que se discutia sobre a responsabilidade internacional do Equador em razão da prisão ilegal e violação dos direitos humanos de Daniel Tibi (comerciante francês de pedras preciosas acusado por tráfico de drogas). Novamente, o juiz Sérgio Garcia Ramirez elaborou voto singular manifestando sobre o controle de convencionalidade.

3. De um modo, a tarefa da Corte se assemelha a que se realiza nos tribunais constitucionais. Estes examinam os atos impugnados - disposições de alcance geral - a luz das normas, os princípios e os valores das leis fundamentais. A Corte Interamericana, entretanto, analisa os atos que chegam ao seu conhecimento em relação às normas, princípios e valores dos tratados que fundam sua competência contenciosa. Dito de outra forma, se os tribunais constitucionais controlam a "constitucionalidade", o tribunal internacional de direitos humanos resolve acerca da "convencionalidade" de tais atos. Através do controle de constitucionalidade, os órgãos internos procuram moldar a atividade do poder público - e, eventualmente, de outros agentes sociais - a ordem que envolveu o Estado de Direito em uma sociedade democrática. 0 tribunal interamericano, entretanto, pretende moldar essa atividade pretende conformar a ordem internacional recebido na convenção fundadora da jurisdição interamericana e aceitos pelos Estados Partes no exercício de suas soberanias. ${ }^{19}$

$\begin{array}{lllll}{ }^{18} \text { CORTE IDH. Caso Myrna Mack Chang Vs. Guatemala. Fondo, Reparaciones y Costas. Sentencia de } 25 \text { de } \\ \text { noviembre } \quad \text { de } 2003 . & \text { Serie } \quad \text { C No. } & \text { No. } & \text { Disponível } & \text { em: }\end{array}$ http://www.corteidh.or.cr/docs/casos/articulos/seriec_101_esp.pdf. Acesso em: 16 jul. 2013. Do original: "Para los efectos de la Convención Americana y del ejercicio de la jurisdicción contenciosa de la Corte Interamericana, el Estado viene a cuentas en forma integral, como un todo. En este orden, la responsabilidad es global, atañe al Estado en su conjunto y no puede quedar sujeta a la división de atribuciones que señale el Derecho interno. No es posible seccionar internacionalmente al Estado, obligar ante la Corte sólo a uno o algunos de sus órganos, entregar a éstos la representación del Estado en el juicio --sin que esa representación repercuta sobre el Estado en su conjunto-- y sustraer a otros de este régimen convencional de responsabilidad, dejando sus actuaciones fuera del "control de convencionalidad" que trae consigo la jurisdicción de la Corte internacional".

${ }_{19}$ CORTE IDH. Caso Tibi Vs. Ecuador. Excepciones Preliminares, Fondo, Reparaciones y Costas. Sentencia de 7 de septiembre de 2004. Serie C No. 114. Disponível em: http://www.corteidh.or.cr/docs/casos/articulos/seriec_114_esp.pdf. Acesso em: 16 jul. 2013. Do original: "En cierto sentido, la tarea de la Corte se asemeja a la que realizan los tribunales 
Em ambas as sentenças expostas acima, o controle de convencionalidade era apenas citado em voto singular do juiz Sérgio Garcia Ramirez, porém, é pelo caso Almonacid Arellano e outros vs. Chile, em sentença de 26 de setembro de 2006, que o controle de convencionalidade é mencionado no corpo da sentença proferida pelo Pleno da Corte Interamericana de Direitos Humanos.

Como aponta Néstor Pedro Sagüés, o controle de convencionalidade é formulado pela Corte no caso Almonacid Arellano e outros vs. Chile, e seus traços essenciais são complementados pelas sentenças proferidas nos casos Trabalhadores demitidos do Congresso vs. Peru, de 24 de novembro de 2006, e, Radilla Pacheco vs. Mexico, 23 de novembro de 2009.

\begin{abstract}
Almonacid Arrelllano sente as linhas fundamentais do controle de constitucionalidade que devem realizar os juízes nacionais, definindo seu papel repressivo (inaplicação das normas locais opostas à Convenção americana sobre direitos do homem e a jurisprudencia da Corte Interamericana). Trabalhores demitidos do Congresso define que esse controle debe ser realizado de ofício, sem pedido da parte. Radilla Pacheco acrescenta o papel construtivo e armonizante do controle: vale dizer, a interpretação e aplicação do direito local seguem as referidas Convenção e jurisprudencia ${ }^{20}$.
\end{abstract}

Ainda, são apontados também como casos essenciais para a evolução do pensamento do controle de convencionalidade dentro da Corte Interamericana de Direitos Humanos: Caso La Cantuta vs. Peru, sentença de 29 de novembro de 2006; Caso Boyce e outros vs. Barbados, sentença de 20 de novembro de 2007; Caso Heliodoro Portugal vs. Panamá, sentença de 12 de

constitucionales. Estos examinan los actos impugnados --disposiciones de alcance general-- a la luz de las normas, los principios y los valores de las leyes fundamentales. La Corte Interamericana, por su parte, analiza los actos que llegan a su conocimiento en relación con normas, principios y valores de los tratados en los que funda su competencia contenciosa. Dicho de otra manera, si los tribunales constitucionales controlan la "constitucionalidad", el tribunal internacional de derechos humanos resuelve acerca de la "convencionalidad" de esos actos. A través del control de constitucionalidad, los órganos internos procuran conformar la actividad del poder público --y, eventualmente, de otros agentes sociales-- al orden que entraña el Estado de Derecho en una sociedad democrática. El tribunal interamericano, por su parte, pretende conformar esa actividad al orden internacional acogido en la convención fundadora de la jurisdicción interamericana y aceptado por los Estados partes en ejercicio de su soberanía".

${ }^{20}$ SAGÜÉS, Néstor Pedro. El "control de convencionalidad" em el sistema interamericano, y sus anticipios em el âmbito de los derechos econômicos-sociales. Concordancias y diferencias com el sistema europeo. Biblioteca jurídica virtual del instituto de investigaciones jurídicas de la UNAM. Disponível em: http://biblio.juridicas.unam.mx/libros/7/3063/16.pdf. Acesso em: 16 jul. 2013. Do original: “Almonacid Arrellano sienta las líneas fundamentales del control de constitucionalidad que deben realizar los jueces nacionales, definiendo su papel represivo (inaplicación de las normas locales opuestas a la Convención americana sobre los derechos del hombre y a la jurisprudencia de la Corte Interamericana). Trabajadores cesados del Congreso define que ese control debe realizarse aun de oficio, sin pedido de parte. Radilla Pacheco añade el papel constructivo y armonizante del control: vale decir, la interpretación y aplicación del derecho local según las referidas Convención y jurisprudencia". 
agosto de 2008; Caso Manuel Cepeda Vargas vs. Colômbia, sentença de 26 de maio de 2010; Caso Comunidade indígena Xákmok Kásek vs. Paraguai, sentença de 24 de agosto de 2010; Caso Fernandez Ortega e outros vs. Mexico, sentença de 30 de agosto de 2010; Caso Rosendo Cantú e outra vs. México, sentença de 31 de agosto de 2010; Caso Vélez Loor vs. Panamá, sentença de 23 de novembro de 2010; Caso Gomes Lund e outros vs. Brasil, sentença de 24 de novembro de 2010; Caso Cabrera García e Montiel Flores vs. México, sentença de 26 de novembro de $2010^{21}$.

Em Almonacid Arellano e outos vs. Chile, houve a responsabilidade internacional do Chile, por, em 15 de setembro de 1998, ter sido protolizado petição requerendo a condenação do Estado do Chile por violação ao acesso à justiça em razão do assassinato de Almonacid Arellano na época do regime militar daquele país.

Na sentença proferida no caso acima, vale citar os itens 124 e 125:

124. A Corte é consciente que os juizes e os tribunais internos estão sujeitos ao império da lei e, por isso, estão obrigados a aplicar as disposições vigentes no ordenamento jurídico. Mas, quando um Estado tenha ratificado um tratado internacional como a Convenção Americana, seus juízes, como parte do aparato do Estado, também estão submetidos à ela, o que os obriga a zelar poruqe os efeitos das disposições da Convenção não prejudica a aplicação de leis contrárias a seu objeto e fim, e que desde o início carecem de efeitos jurídicos. Em outras palavras, o Poder Judiciário deve exercer uma espécie de "controle de convencionalidade" entre as normas jurídicas internas que aplicam nos casos concretos e a Convenção Americana de Direitos Humanos. Nesta tarefa, o Poder Judiciário deve levar em conta não apenas o tratado, mas também a interpretação de que o mesmo recebe da Corte Interamericana, intérprete última da Convenção Americana.

125. Nestas mesmas linhas de ideias, esta Corte já estabeleceu que "segundo o direito internacional as obrigações que este impõe devem ser cumpridas de boa fé e não pode invocar, para seu descumprimento, o direito interno. Esta regra foi codificada no artigo 27 da Convenção de Viena sobre os direitos dos tratados de $1969 .{ }^{22}$

\footnotetext{
${ }^{21}$ RUSSOWSKY, Iris Saraiva. O controle de convencionalidade das leis: uma análise na esfera internacional e interna. RIBD - Revista do Instituto do Direito Brasileiro. ano 1. n. 3. 2012. Disponível em: http://www.idb-fdul.com/uploaded/files/2012_03_1745_1826.pdf. Acesso em: 16 jul. 2013.

${ }_{22}$ Corte IDH. Caso Almonacid Arellano y otros Vs. Chile. Excepciones Preliminares, Fondo, Reparaciones y Costas. Sentencia de 26 de septiembre de 2006. Serie C No. 154. http://www.corteidh.or.cr/docs/casos/articulos/seriec_154_esp.pdf. Acesso em: 16 jul. 2013. Do original: “124. La Corte es consciente que los jueces y tribunales internos están sujetos al imperio de la ley y, por ello, están obligados a aplicar las disposiciones vigentes en el ordenamiento jurídico. Pero cuando un Estado ha ratificado un tratado internacional como la Convención Americana, sus jueces, como parte del aparato del Estado, también están sometidos a ella, lo que les obliga a velar porque los efectos de las disposiciones de la Convención no se vean mermadas por la aplicación de leyes contrarias a su objeto y fin, y que desde un inicio carecen de efectos jurídicos. En otras palabras, el Poder Judicial debe ejercer una especie de "control de convencionalidad" entre las normas jurídicas internas que aplican en los casos concretos y la Convención Americana sobre Derechos Humanos. En esta tarea, el Poder Judicial debe tener en cuenta no solamente el tratado, sino también la interpretación que del mismo ha hecho la
} 
Como se observa nos itens expostos acima, com a sentença proferida neste caso, ficou consolidado o pensamento do controle de convencionalidade que deve ser realizado não apenas pela Corte Interamericana, mas também pelos juízes e tribunais nacionais (controle difuso), tendo como base não apenas o Pacto de San José da Costa Rica, mas também, a jurisprudencia firmada pela Corte Interamericana, já que esta é considerada como a intérprete última da Convenção Interamericana de Direitos Humanos.

\section{A CRIAÇÃO DO BLOCO DE CONVENCIONALIDADE NAS DECISÕES DA CORTE INTERAMERICANA DE DIREITOS HUMANOS}

Conforme exposto anteriormente, é no caso Almonacid Arellano e outros vs. Chile que o Pleno da Corte Interamericana passa a, efetivamente, aplicar o controle de convencionalidade em suas decisões, fortalecendo este pensamento nos demais casos apreciados por este Tribunal Internacional.

Nesta construção jurisprudencial, surgiu a ideia do bloco de convencionalidade, mais precisamente a partir da sentença proferida no caso Trabalhadores demitidos do Congresso vs. Peru, sentença de 24 de novembro de 2006.

O bloco de convencionalidade também é novamente citado nos casos Ibsen Cárdenas $e$ Ibsen Peña vs. Bolívia, sentença de 01 de setembro de 2010 e Cabrera García e Montiel Flores vs. México, sentença de 26 de novembro de 2010, a qual serão tratados abaixo.

Inicialmente, com base em uma ordem cronológica, no caso Trabalhadores demitidos do Congresso vs. Peru, sentença de 24 de novembro de 2006, houve a demissão imprópria de 257 trabalhadores do Congresso da República do Perú em 1992. A violação aos direitos humanos ficou configurada, em especial, pela arbitrariedade da demissão e desrespeito as normas trabalhistas.

Neste caso se consagrou o entendimento, pela Corte, que juízes e tribunais nacionais poderiam realizar o controle de convencionalidade de ofício, garantindo uma melhor produção de efeitos da Convenção Americana de Direitos Humanos. É o que se observa no item 128 da sentença:

Corte Interamericana, intérprete última de la Convención Americana. 125. En esta misma línea de ideas, esta Corte ha establecido que "[s]egún el derecho internacional las obligaciones que éste impone deben ser cumplidas de buena fe y no puede invocarse para su incumplimiento el derecho interno". Esta regla ha sido codificada en el artículo 27 de la Convención de Viena sobre el Derecho de los Tratados de 1969". 
128. Quando um Estado tenha ratificado um tratado internacional como a Covenção Americana, seus juízes também estão submetidos a ela, o que os obriga a zelar, porque a eficácia da Convenção não está prejudicada ou anulada pela aplicação das leis contrárias a suas disposições, objeto e fim. Em outras palavras, os órgãos do Poder Judiciário devem exercer não apenas um contrle de constitucionalidade, senão também, de convencionalidade ex officio entre as normas internas e a Convenção Americana, evidentemente que o marco de suas respectivas competências e dos regulamentos processuais correspondentes. Esta função não deve permanecer limitada exclusivamente pelas manifestações ou atos dos acionantes em cada caso concreto, embora tampouco implica que esse controle deva ser exercido sempre, sem considerar outros presuspostos formais e materiais de admissibilidade e procedência deste tipo de ações. ${ }^{23}$

Também, na fundamentação do voto do juiz Sergio García Ramírez, é mencionado que o controle de convencionalidade não deve estar restrito apenas as normas do Pacto de San José da Costa Rica, mas também a outros Tratados Internacionais de Direitos Humanos ratificados por um Estado-membro, que juntos, formam um corpus juris convencional de direitos humanos.

2. Em espécie, ao referir a um "controle de convencionalidade" a Corte Interamericana tem em mente a aplicabilidade e aplicação da Convenção Americana sobre Direitos Humanos, Pacto de São José. Sem embargos, a mesma função se monitora, por idênticas razões, no que concerne a outros instrumentos de igual natureza, integrandes do corpus juris convencional dos direitos humanos de que o Estado é parte: Protocolo de São Salvador, Protoloco relativo a Abolição da Pena de Morte, Convenção para Previnir e Sancionar a Tortura, Convenção do Belém do Pará para Erradicação da Violência contra a Mulher, Convenção sobre Desaparecimento Forçado, etc. 0 que se tem é a consistência interna entre as ações e os compromissos assumidos pelo Estado que geraram para este determinados deveres e o reconhecimento aos indivídios de certos direitos. ${ }^{24}$

${ }^{23}$ CORTE IDH. Caso Trabajadores Cesados del Congreso (Aguado Alfaro y otros) Vs. Perú. Excepciones Preliminares, Fondo, Reparaciones y Costas. Sentencia de 24 de Noviembre de 2006. Serie C No. 158. Disponível em: http://www.corteidh.or.cr/docs/casos/articulos/seriec_174_esp.pdf. Acesso em: 16 jul. 2013. Do originial: "Cuando un Estado ha ratificado un tratado internacional como la Convención Americana, sus jueces también están sometidos a ella, lo que les obliga a velar porque el efecto útil de la Convención no se vea mermado o anulado por la aplicación de leyes contrarias a sus disposiciones, objeto y fin. En otras palabras, los órganos del Poder Judicial deben ejercer no sólo un control de constitucionalidad, sino también "de convencionalidad" ex officio entre las normas internas y la Convención Americana, evidentemente en el marco de sus respectivas competencias y de las regulaciones procesales correspondientes. Esta función no debe quedar limitada exclusivamente por las manifestaciones o actos de los accionantes en cada caso concreto, aunque tampoco implica que ese control deba ejercerse siempre, sin considerar otros presupuestos formales y materiales de admisibilidad y procedencia de ese tipo de acciones".

${ }^{24}$ CORTE IDH. Caso Trabajadores Cesados del Congreso (Aguado Alfaro y otros) Vs. Perú. Excepciones Preliminares, Fondo, Reparaciones y Costas. Sentencia de 24 de Noviembre de 2006. Serie C No. 158. Disponível em: http://www.corteidh.or.cr/docs/casos/articulos/seriec_174_esp.pdf. Acesso em: 16 jul. 2013. Do original: "En la especie, al referirse a un "control de convencionalidad" la Corte Interamericana ha tenido a la vista la aplicabilidad y aplicación de la Convención Americana sobre Derechos Humanos, Pacto de San José. Sin embargo, la misma función se despliega, por idénticas razones, en lo que toca a 
Vale apontar que, anteriormente, no caso Almonacid Arellano e outros vs. Chile, a Corte firmou entendimento de que os juízes nacionais devem se valer não apenas do Pacto de São José da Costa Rica, mas também da jurisprudencia da Corte Interamericana. Como se observa no caso Trabalhadores demitidos do Congresso vs. Perú, além de observar a Convenção, também devem os juízes analisar em conjunto os demais Tratados Internacionais de Direitos Humanos ratificados pelo Estado.

Já em 01 de setembro de 2010, foi dada sentença no caso Ibsen Cárdenas e Ibsen Peña vs. Bolívia, declarando a responsabilidade internacional da Bolívia pelo desaparecimento forçado de Rainer Ibsen Cárdenas e José Luis Ibsen Peña, durante a época da ditadura militar daquele país.

$\mathrm{Na}$ fundamentação do Pleno, entendeu que "el Tribunal recuerda que el objeto de su mandato es la aplicación de la Convención Americana y de otros tratados que le otorguen competencia"25.

Ainda, nesta mesma sentença, a Corte Interamericana reiterou o pensamento firmado no caso Almonacid Arellano e outos vs. Chile, sobre o controle difuso de convencionalidade e a necessidade de observar não apenas o Pacto de San José da Costa Rica, mas também a jurisprudencia da Corte.

202. A Corte é consciente que os juizes e os tribunais internos estão sujeitos ao império da lei e, por isso, estão obrigados a aplicar as disposições vigentes no ordenamento jurídico. Mas, quando um Estado tenha ratificado um tratado internacional como a Convenção Americana, seus juízes, como parte do aparato do Estado, também estão submetidos à ela, o que os obriga a zelar porque os efeitos das disposições da Convenção não prejudica a aplicação de leis contrárias a seu objeto e fim, e que desde o início carecem de efeitos jurídicos. Em outras palavras, o Poder Judiciário deve exercer uma espécie de "controle de convencionalidade" ex officio entre as normas jurídicas internas que aplicam nos casos concretos e a Convenção Americana, evidentemente o marco de suas respectivas competências e suas regulações processuais correspondentes. Nesta tarefa, o Poder Judiciário deve levar em conta não somente o tratado, mas

otros instrumentos de igual naturaleza, integrantes del corpus juris convencional de los derechos humanos de los que es parte el Estado: Protocolo de San Salvador, Protocolo relativo a la Abolición de la Pena de Muerte, Convención para Prevenir y Sancionar la Tortura, Convención de Belém do Pará para la Erradicación de la Violencia contra la Mujer, Convención sobre Desaparición Forzada, etcétera. De lo que se trata es de que haya conformidad entre los actos internos y los compromisos internacionales contraídos por el Estado, que generan para éste determinados deberes y reconocen a los individuos ciertos derechos".

${ }^{25}$ CORTE IDH. Caso Ibsen Cárdenas e Ibsen Peña Vs. Bolivia. Fondo, Reparaciones y Costas. Sentencia de 1 de septiembre de 2010 Serie C No. 217. Disponível em: http://www.corteidh.or.cr/docs/casos/articulos/seriec_217_esp1.pdf. Acesso em: 16 jul. 2013. 
também, a interpretação que o mesmo foi atribuído pela Corte Interamericana, intérprete última da Convenção Amerciana. ${ }^{26}$

Por fim, é no caso Cabrera Garcia e Montiel Flores vs. México, sentença de 26 de novembro de 2010, cujo se trata da responsabilidade internacional do Estado do México por ter submetido Teodoro Cabrera García e Rodolfo Montiel Flores a tratamento cruel, desumano e degradante pelo exército, sem apresentação em tempo hábil a um juiz de direito, como por irregularidades processuais ${ }^{27}$, que há a menção expressa à figura do "bloco de convencionalidade".

Tem-se aqui uma das decisões mais significativas da Corte, em razão da construção do controle de convencionalidade, pois, a fundamentação da mesma é baseada em todo histórico criado pelo Tribunal Internacional sobre o tema.

Sobre o reconhecimento da existencia de um bloco de convencionalidade, cita-se o item 50 da decisão acima:

50. Se forma desta maneira um autêntico "bloco de convencionalidade" como parâmetro para o exercício do "controle difuso de convencionalidade". Os juízes nacionais devem atender a este "bloco", o que implica, por parte deles, uma permanente atualização da jurisprudência da Corte IDH e propicia uma "interação viva" entre as jurisprudências nacionais e interamericana, com a finalidade última de estabelecer normas em nossa região para a proteção efetiva dos direitos humanos. ${ }^{28}$

${ }^{26}$ CORTE IDH. Caso Ibsen Cárdenas e Ibsen Peña Vs. Bolivia. Fondo, Reparaciones y Costas. Sentencia
de 1 de septiembre de 2010 Serie C No. 217. Disponível em: http://www.corteidh.or.cr/docs/casos/articulos/seriec_217_esp1.pdf. Acesso em: 16 jul. 2013. Do original: "Por otra parte, la Corte considera oportuno reiterar que en relación con las prácticas judiciales, este Tribunal ha establecido en su jurisprudencia que es consciente de que los jueces y tribunales internos están sujetos al imperio de la ley y, por ello, están obligados a aplicar las disposiciones vigentes en el ordenamiento jurídico. Pero cuando un Estado ha ratificado un tratado internacional como la Convención Americana, sus jueces, como parte del aparato del Estado, también están sometidos a ella, lo que les obliga a velar porque los efectos de las disposiciones de la Convención no se vean mermados por la aplicación de leyes contrarias a su objeto y fin, que desde un inicio carecen de efectos jurídicos. En otras palabras, el Poder Judicial está llamado a ejercer un "control de convencionalidad" ex officio entre las normas internas y la Convención Americana, evidentemente en el marco de sus respectivas competencias y de las regulaciones procesales correspondientes. En esta tarea, el Poder Judicial debe tener en cuenta no solamente el tratado, sino también la interpretación que del mismo ha hecho la Corte Interamericana, intérprete última de la Convención Americana".

${ }^{27}$ RUSSOWSKY, Iris Saraiva. O controle de convencionalidade das leis: uma análise na esfera internacional e interna. RIBD - Revista do Instituto do Direito Brasileiro. ano 1. n. 3. 2012. Disponível em: http://www.idb-fdul.com/uploaded/files/2012_03_1745_1826.pdf. Acesso em: 16 jul. 2013.

${ }_{28}$ CORTE IDH. Caso Cabrera García y Montiel Flores Vs. México. Excepción Preliminar, Fondo, Reparaciones y Costas. Sentencia de 26 de noviembre de 2010 Serie C No. 220. Disponível em: http://www.corteidh.or.cr/docs/casos/articulos/seriec_220_esp.pdf. Acesso em: 16 jul. 2013. Do original: "Se forma de esta manera un auténtico "bloque de convencionalidad" como parámetro para ejercer el "control difuso de convencionalidad". Los jueces nacionales deben atender a este "bloque", lo 
Portanto, é com a sentença do caso Cabrera García e Montiel Flores vs. México, que consolida o pensamento do bloco de convencionalidade, a qual passará a tratar.

\title{
4 A APLICAÇÃO DO BLOCO DE CONVENCIONALIDADE DE ACORDO COM A CORTE INTERAMERICANA DE DIREITOS HUMANOS
}

Como foi demonstrado anteriormente, a criação de um bloco de convencionalidade faz parte da evolução jurisprudencial da Corte Interamericana de Direitos Humanos em razão do controle de convencionalidade.

A expressão bloco de convencionalidade foi utilizada pela primeira vez no caso Cabrera García e Montiel Flores vs. México, todavia, já apresentava sua forma em sentenças anteriores.

A conceituação de um bloco de convencionalidade pode ser retirada do item 26 da sentença citada acima.

\begin{abstract}
26. O desenvolvimento descrito de incorporação do direito internacional de direitos humanos em sede nacioal, também se deve as próprias jurisdições domésticas, especialmente as altas jurisdições constitucionais, que, progressivamente, têm privilegiado intepretações dinâmicas que favorecem e possibilitam a recepção dos direitos humanos previstos nos tratados internacionais. Se forma um autêntico "bloco de constitucionalidade", que varia de país a país, a tendência é considerar dentro de um mesmo solo aos direitos humanos previstos nos pactos internacionais, senão também a própria jurisprudência da Corte IDH. Assim, em algumas ocasiões o "bloco de convencionalidade" é subsumido no "bloco de constitucionalidade", porque, ao realizar o "controle de constitucionalidade" também se efetua o "controle de convencionalidade". ${ }^{29}$
\end{abstract}

que implica, por parte de ellos, una permanente actualización de la jurisprudencia de la Corte IDH y propicia una "viva interacción" entre las jurisdicciones nacionales y la interamericana, con la finalidad última de establecer estándares en nuestra región para la protección efectiva de los derechos humanos".

${ }_{29}$ CORTE IDH. Caso Cabrera García y Montiel Flores Vs. México. Excepción Preliminar, Fondo, Reparaciones y Costas. Sentencia de 26 de noviembre de 2010 Serie C No. 220. Disponível em: http://www.corteidh.or.cr/docs/casos/articulos/seriec_220_esp.pdf. Acesso em: 16 jul. 2013. Do original: "El desarrollo descrito de incorporación del derecho internacional de los derechos humanos en sede nacional, también se debe a las propias jurisdicciones domésticas, especialmente a las altas jurisdicciones constitucionales, que progresivamente han privilegiado interpretaciones dinámicas que favorecen y posibilitan la recepción de los derechos humanos previstos en los tratados internacionales.43 Se forma un auténtico "bloque de constitucionalidad", que si bien varía de país a país, la tendencia es considerar dentro del mismo no sólo a los derechos humanos previstos en los pactos internacionales, sino también a la propia jurisprudencia de la Corte IDH. Así, en algunas ocasiones el "bloque de convencionalidad" queda subsumido en el "bloque de constitucionalidad", por ló que al realizar el "control de constitucionalidad" también se efectúa "control de convencionalidad". 
No item acima se percebe a preocupação da Corte Interamericana na implementação efetiva do Direito Internacional dos Direitos Humanos no ordenamento jurídico interno de um Estado-membro, que, preferencialmente é realizado pelos Tribunais Constitucionais de cada país, valendo-se de instrumentos de garantia e proteção dos direitos humanos, em especial os Tratados Internacionais de Direitos Humanos, que, somando-se, cria um bloco de constitucionalidade, e, consequentemente, também cria um bloco de convencionalidade, pois, além de realizar um controle de constitucionalidade, os juízes nacionais, devem realizar, em caráter complementar e coadjuvante, um controle de convencionalidade.

Se observarmos com atenção os alcances do "controle difuso de convencionalidade", podemos advertir que na realidade não é algo novo. Trata-se de uma espécie de "bloco de constitucionalidade" derivado de uma constitucionalização do direito internacional dos direitos humanos, ou pelas reformas que as próprias constituições nacionais vêm realizando ou através dos alcances da jurisprudência constitucional que aceitaram. ${ }^{30}$

Logo, a ideia de um bloco de convencionalidade é ligada a ideia de um bloco de constitucionalidade.

Anteriormente da construção do pensamento do controle de convencionalidade pela Corte Interamericana de Direitos Humanos, os Tratados Internacionais de Direitos Humanos eram interpretados em grande parte dos países da América Latina, como um elemento que integrava o bloco de constitucionalidade de cada país. Com a imposição, pela Corte Interamericana, da aplicação do próprio Pacto de São José da Costa Rica como também de sua jurisprudência formada é que passa a surgir o controle de convencionalidade no sistema interamericano. Por essa razão já citou que é necessário entender que o controle de convencionalidade é complementar e coadjuvante com o controle de constitucionalidade, pois, se para vários países da América Latina a utilização dos Tratados Internacionais de Direitos Humanos integrava um bloco de constitucionalidade, a utilização dos mesmos tratados juntamente com a jurisprudência

\footnotetext{
${ }^{30}$ MAC-GREGOR, Eduardo Ferrer. Interpretación conforme y control difuso de convencionalidad. El nuevo paradigma para el juez mexicano. Estudios Constitucionales. ano 9. n. 2. 2011. Disponível em: http://www.conatrib.org.mx/html/Paneles/Paneles/PanelVIII_InterpretaciónConformeControlDifusoConve ncionalidad_EduardoFerrer.pdf. Acesso em: 16 jul. 2013. Do original: "Si observamos con atención los alcances del "control difuso de convencionalidad", podemos advertir que en realidad no es algo nuevo. Se trata de uma especie de "bloque de constitucionalidad" derivado de una constitucionalización del derecho internacional de los derechos humanos, sea por las reformas que las propias constituciones nacionales han venido realizando o a través de los avances de la jurisprudencia constitucional que la han aceptado".
} 
da Corte Interamericana, resultará, tanto em um controle de constitucionalidade como, simultaneamente, em um controle de convencionalidade.

Todavia, no Brasil, por exemplo, ainda se discute sobre um conceito e aplicação do bloco de constitucionalidade, prevalecendo ainda uma interpretação restritiva sobre essa figura jurídica. Tanto que, o Ministro do Supremo Tribunal Federal Celso de Mello, no julgamento da ADI 595/ES (Informativo 258/STF) passou a difundir a ideia de um bloco de constitucionalidade no Brasil, porém, de uma forma "fechada". Para o douto Ministro, o bloco de constitucionalidade seria um parâmetro de preceitos explícitos e implícitos incorporados na Constituição formal ${ }^{31}$.

Entretanto, trata-se de um posicionamento ainda tímido, não correspondendo a doutrina internacional. Por bloco de constitucionalidade, deve-se entender como o conjunto de normas constitucionais materiais (normas que se encontram fora da Constituição, porém que carregam, na expressão de Jorge Miranda, “o espírito da Constituição”) e formais (normas inseridas dentro da Constituição) que, em conjunto, servem como parâmetro para o controle de compatibilidade de normas infraconstitucionais à própria Constituição.

Assim, o bloco de convencionalidade, no âmbito do sistema de proteção interamericana de direitos humanos, deve ser visto como o conjunto de normas materiais e formais do Pacto de São José da Costa Rica, que serviram como parâmetro para análise da compatibilidade de uma norma nacional à garantia e proteção dos direitos humanos. Vale apontar que, a não compatibilidade de uma norma interna com o bloco de convencionalidade resulta na não produção de efeitos jurídicos daquela, sendo que sua própria existência - da lei interna - já carece de efeitos jurídicos por si própria, por ser inconvencional.

Neste sentido, o resultado do exame de compatibilidade entre a norma nacional e o bloco de convencionalidade consiste em deixar sem efeitos jurídicos aquelas interpretações inconvencionais ou as que são menos favoráveis; Ou bem, quando no pode aplicar interpretação convencional alguma, a consequência consiste em deixar sem efeitos jurídicos a norma nacional, ou no caso particular ou com efeitos gerais realizando uma declaração de invalidade de conformidade com as atribuições do juiz que realizou o controle - que, no caso do juiz do controle, unicamente pode ter na aplicação da norma inconvencional ao caso concreto que está conhecendo. ${ }^{32}$

\footnotetext{
${ }^{31}$ PUCCINELLI JUNIOR, André. Curso de direito constitucional. 1. ed. São Paulo: Saraiva. 2.012.

32 BENAVANTE CHORRES, Hesbert. El juez de control como garante de la convencionalidad de las normas en el nuevo proceso penal mexicano. Estudios Constitucionales. ano 10. n. 1. 2012. p. 145-200. Disponível em: http: / / www.scielo.cl/scielo.php?pid=S0718-52002012000100005\&script=sci_arttext. Acesso em: 16 jul. 2013. Do original: "En ese sentido, el resultado del examen de compatibilidad entre la norma
} 
Pode-se dizer que o bloco de convencionalidade teve início com a sentença do caso Almonacid Arellano e outos vs. Chile, pois, naquela ocasião, entendeu o Tribunal Internacional que, para os juízes realizassem um efetivo controle difuso de convencionalidade, os mesmos deveriam se valer não apenas das regras do Pacto de São José da Costa Rica, mas também, da interpretação que a Corte Interamericana mantinha do Pacto, ou seja, ir além de um instrumento normativo-base. O que leva ao curioso fato de que, a construção do controle de convencionalidade nas decisões da Corte Interamericana é simultânea a criação de um bloco de convencionalidade, ou seja, a preocupação deste Tribunal Internacional não se limitou, no início, apenas a criação de um novo controle jurisdicional das leis, mas também, ao fortalecimento do parâmetro para esse novo controle, e ainda, um parâmetro acompanhando a majoritária doutrina estrangeira sobre o bloco de constitucionalidade, a contrasenso do Brasil, com sua interpretação restritiva do que englobaria tal bloco.

É o que se percebe no item 45 do voto singular do juiz Eduardo Ferrer Mac-Gregor Poisot, no caso Cabrera García e Montiel Flores vs. México, ao mencionar a existência de um corpus juris interamericano em defesa dos direitos humanos:

\begin{abstract}
45. Não obstante, a própria "jurisprudência" da Corte IDH foi ampliando o corpus juris interamericano em matéria de direitos humanos para fundamentar seus julgamentos. Não deve passar despercebido que é o próprio Pacto de São José que permite incluir "o regime de proteção desta Convenção, outros direitos e liberdades que são reconhecidos de acordo com os artigos 76 e 77", o que se permitiu que se aprovavem diversos Protocolos "adicioais" (à Convenção Americana) e serem interpretados por este Tribual Interamericano. Também, o próprio Pacto estabelece como norma interpretativa que não se pode exlucir ou limitar o efeito que podem produzir a Declaração Americana de Direitos e Deveres do Homem e "outros atos internacionais de mesma natureza". ${ }^{33}$
\end{abstract}

\begin{abstract}
nacional y el bloque de convencionalidad consiste em dejar si efectos jurídicos aquellas interpretaciones inconvencionales o las que Sean menos favorables; o bien, cuando no puede lograrse interpretación convencional alguna, la consecuencia consiste em dejar sin efectos jurídicos la norma nacional, ya sea en el caso particular o com efectos generales realizando la declaración de invalidez de conformidad con las atribuciones del juez que realice dicho control - que en el caso del juez de control, únicamente podrá disponer la no aplicación de la norma inconvencional al caso concreto que está conociendo".

${ }_{33}$ CORTE IDH. Caso Cabrera García y Montiel Flores Vs. México. Excepción Preliminar, Fondo, Reparaciones y Costas. Sentencia de 26 de noviembre de 2010 Serie C No. 220. Disponível em: http://www.corteidh.or.cr/docs/casos/articulos/seriec_220_esp.pdf. Acesso em: 16 jul. 2013. Do original: "No obstante, la propia "jurisprudencia" de la Corte IDH ha ido ampliando el corpus juris interamericano en materia de derechos humanos para fundamentar sus fallos. No debe pasar inadvertido que es el propio Pacto de San José el que permite incluir "en el régimen de protección de esta Convención otros derechos y libertades que sean reconocidos de acuerdo con los artículos 76 y 77", lo que ha permitido que se aprueben diversos Protocolos "adicionales" (a la Convención Americana) y sean interpretados por este Tribunal Interamericano. Asimismo, el propio Pacto establece como norma
\end{abstract}


A expressão corpus juris é atribuída à Dionísio Godofredo, no século XVI, ao denominar a codificação de Justiniano, publicada nos anos de 529 a 534 no Imperio Bizantino, que era formada pelas Institutas, Digesto, Código e Novelas. Como se sabe, o corpus juris civilis de Justiniano não se limitava apenas a uma compilação de leis (Codex), mas também em jurisprudencias, doutrinas, manual introdutório e constituições, todas ligadas ao propósito de unificar o direito ordenado pelo imperador ${ }^{34}$. Percebe-se que o pensamento que Justiniano detinha em seu compêndio era que diversos instrumentos jurídicos, com natureza jurídica distinta entre si, possuiam uma finalidade em comum, devendo ser analisadas em conjunto, formando, portanto, um verdeiro corpo jurídico. Essa é a mesma interpretação que o juiz Eduardo Ferrer Mac-Gregor Poisot faz ao tratar do bloco de convencionalidade, dispondo que existe a necessidade de interpretação não apenas das normas como da jurisprudencia da Corte Interamericana.

Ainda com base no item 45, o juiz Eduardo Ferrer, para fortalecer o pensamento do bloco de convencionalidade, aponta que a possibilidade de adoção desse tipo de parâmetro é concedida pelo próprio Pacto de São José da Costa Rica, já que, nos artigos 76 e 77 do Tratado, dispõe a possibilidade dos Estados-membros inserirem protocolos adicionais que fortaleçam a própria Convenção. É o que se observa no artigo 77 transcrito abaixo:

Artigo 77 - 1. De acordo com a faculdade estabelecida no artigo 31, qualquer Estado-parte e a Comissão podem submeter à consideração dos Estados-partes reunidos por ocasião da Assembléia Geral projetos de Protocolos adicionais a esta Convenção, com a finalidade de incluir progressivamente, no regime de proteção da mesma, outros direitos e liberdades.

Importante apontar que, essa possibilidade já havia sido aplicada no caso Trabalhadores demitidos do congresso vs. Perú, em citação já apresentada anteriormente, cujo o juiz Nestor García Ramírez, mencionando a existência de um corpus juris convencional, representado por outros Tratados Internacionais de Direitos Humanos ratificados pelo Peru, como também no caso Ibsen Cárdenas e Ibsen Peña vs. Bolívia, também apresentado anteriormente. Porém, muito antes da aplicação em casos contenciosos, a Corte Interamericana já tratava sobre a existência de um corpus juris, todavia, não especificamente atribuindo ao controle de convencionalidade.

interpretativa que no se puede excluir o limitar el efecto que puedan producir la Declaración Americana de Derechos y Deberes del Hombre y "otros actos internacionales de la misma naturaleza".

${ }^{34}$ CORREIA, Alexandre. SCIASCIA, Gaetano. Manual de direito romano. 5. ed. Estado da Guanabara: Série “Caderno Didáticos”. 1969. 
Na Opinião Consultiva OC-16/99, a Corte se manifestou da existência de um corpus juris de Direito Internacional de Direitos Humanos, em um sentido geral.

O corpus juris do Direito Internacioal dos Direitos Humanos está formado por um conjunto de instrumentos internacionais de conteúdo e efeitos jurídicos variados (tratados, convenções, resoluções e declarações). Sua evolução dinâmica tem exercido um impacto positivo no Direito Internacional, no sentido de afirmar e desenvolver a aplitude deste último para regular as relações entre os Estados e os seres humanos diante suas respectivas jurisdições. Para tanto, esta Corte deve abotar um critério adequado para considerar a questão sujeita a exame em marco da evolução dos direitos fundamentais da pessoa humana e o direito internacional contemporâneo. ${ }^{35}$

A menção desse corpus juris é tão ampla que, o juiz nacional, ao realizar o controle difuso de convencionalidade, utilizando como paradigma o bloco de convencionalidade estará se obrigando não apenas a respeitar o Pacto de São José da Costa Rica ou os demais Tratados Internacionais de Direitos Humanos ratificados, porém, também, de forma implícita, demais Tratados Internacionais de Direitos Humanos que seu Estado não ratificou. Isso porque, caso uma sentença, opinião consultiva ou qualquer outro instrumento de interpretação da Corte Interamericana se basear em um Tratado Internacional de Direitos Humanos não ratificado pelo Estado-membro, mesmo assim, este se vincularia a interpretação dada ao tratado estranho ao seu ordenamento jurídico.

Desta maneira, por exemplo, podem formar parte de sua jurisprudência, as normas estabelecidas pela Corte Européia de Direitos Humanos, tratados internacionais do sistema universal, as resoluções dos Comitês das Nações Unidas, as recomendações da Comissão Interamericana de Direitos Humanos, ou mesmo os informes dos relatores especiais da OEA e das Nações Unidas, entre outros, sempre e quando a Corte IDH os utilizar e endossá-los para formar sua interpretação do corpus juris interamericano e criar a norma convencional interpretada como norma interamericana. ${ }^{36}$

\footnotetext{
${ }^{35}$ CORTE IDH. El Derecho a la Información sobre la Asistencia Consular en el Marco de las Garantías del Debido Proceso Legal. Opinión Consultiva OC-16/99 de 1 de octubre de 1999. Serie A No. 16. http://www.corteidh.or.cr/docs/opiniones/seriea_16_esp.pdf. Acesso em: 16 jul. 2013. Do original: "El corpus juris del Derecho Internacional de los Derechos Humanos está formado por un conjunto de instrumentos internacionales de contenido y efectos jurídicos variados (tratados, convenios, resoluciones y declaraciones). Su evolución dinámica ha ejercido un impacto positivo en el Derecho Internacional, en el sentido de afirmar y desarrollar la aptitud de este último para regular las relaciones entre los Estados y los seres humanos bajo sus respectivas jurisdicciones. Por lo tanto, esta Corte debe adoptar un criterio adecuado para considerar la cuestión sujeta a examen en el marco de la evolución de los derechos fundamentales de la persona humana en el derecho internacional contemporáneo".

${ }^{36}$ MAC-GREGOR, Eduardo Ferrer. Interpretación conforme y control difuso de convencionalidad. El nuevo paradigma para el juez mexicano. Estudios Constitucionales. ano 9. n. 2. 2011. Disponível em: http://www.conatrib.org.mx/html/Paneles/Paneles/PanelVIII_InterpretaciónConformeControlDifusoConve ncionalidad_EduardoFerrer.pdf. Acesso em: 16 jul. 2013. Do original: "De esta manera, por ejemplo,
} 
Tem-se aqui o pensamento da "jurisprudência convencional", defendida pelo juiz Eduardo Ferrer Mac-Gregor ${ }^{37}$. Tal jurisprudência convencional é, necessariamente, baseada em uma interpretação que condiz com as características dos Tratados Internacionais de Direitos Humanos, ou seja, sempre mantendo uma visão atual, baseada na evolução da luta pelos Direitos Humanos.

Também, o juiz nacional deve aplicar a jurisprudência convencional, mesmo naqueles assuntos onde não são parte o Estado Nacional que pertence, já que o que define a integração da jurisprudência da Corte Interamericana, orientada a criar uma norma na região sobre a aplicabilidade e efetividade do corpus juris interamericano. ${ }^{38}$

A importância dessa interpretação ampliativa e assim, a aceitação da aplicação de jurisprudências da Corte com base em Tratados Internacionais de Direitos Humanos estranhos a um Estado-membro pelo juiz nacional se faz necessário, pois, se, por exemplo, o Estado-juiz optar pela aplicação apenas das jurisprudências em que o país fora parte ou que é baseada em Tratados Internacionais de Direitos Humanos ratificados, perde-se a busca de um padrão de proteção ao sistema de proteção interamericana de direitos humanos, uma vez que haveria desproporcionalidade na aplicação da responsabilidade internacional de cada Estado-membro, e, consequentemente, o enfraquecimento da própria força do sistema interamericano de direitos humanos.

Para tanto, uma das soluções que alguns países da América Latina vêm adotando é da aplicação da cláusula de interpretação conforme o direito comparado, como se observa no artigo $1^{\circ}$ da Constituição do México:

pueden formar parte de su jurisprudencia los estándares establecidos por la Corte Europea de Derechos Humanos, tratados internacionales del sistema universal, las resoluciones de los Comités de Naciones Unidas, las recomendaciones de la Comisión Interamericana de Derechos Humanos o incluso los informes de los relatores especiales de la OEA o de Naciones Unidas, entre otros, siempre y cuando la Corte IDH los utilice y los haga suyos para formar su interpretación del corpus juris interamericano y crear la norma convencional interpretada como estándar interamericano".

${ }^{37}$ MAC-GREGOR, Eduardo Ferrer. Interpretación conforme y control difuso de convencionalidad. El nuevo paradigma para el juez mexicano. Estudios Constitucionales. ano 9. n. 2. 2011. Disponível em: http:// www.conatrib.org.mx/html/Paneles/Paneles/PanelVIII_InterpretaciónConformeControlDifusoConve ncionalidad_EduardoFerrer.pdf. Acesso em: 16 jul. 2013.

${ }^{38}$ BENAVANTE CHORRES, Hesbert. El juez de control como garante de la convencionalidad de las normas en el nuevo proceso penal mexicano. Estudios Constitucionales. ano 10. n. 1. 2012. p. 145-200. Disponível em: http://www.scielo.cl/scielo.php?pid=S0718-52002012000100005\&script=sci_arttext. Acesso em: 16 jul. 2013.. Do original: "Asimismo, el juez nacional debe aplicar la jurisprudencia convencional, aun en aquellos asuntos donde no sea parte el Estado nacional al que pertenece, ya que lo define la integración de la jurisprudencia de la Corte Interamericana, orientada a crear um estándar em la región sobre la aplicabilidad y efectividad del corpus iuris interamericano". 
Artigo $1^{\circ}$. Nos Estados Unidos Mexicanos, todas as pessoas gozarão dos direitos humanos reconhecidos por esta Constituição e nos tratados internacionais que o Estado Mexicano é parte, assm como as garantias e proteções, cujo exercício não poderá se restringir ou suspender, salvo nos casos e baixo as condições que esta Constituição estabelece.

As normas relativas aos direitos humanos serão interpretadas em conformidade com esta Constituição e com os tratados internacionais cuja matéria favoreça a todo o tempo as pessoas com a interpretação mais ampla.

Como se observa, o artigo $1^{\circ}$ da Constituição Mexicana inseriu uma cláusula que determina a realização de uma interpretação harmônica entre a Constituição e os Tratados Internacionais de Direitos Humanos, referentes a normas que tratam sobre direitos humanos, sendo que deve sempre prevalecer uma interpretação ampla. Assim, com a aplicação dessa cláusula de interpretação em conjunto da Constituição com os Tratados Internacionais, o pensamento da aplicação de um bloco de convencionalidade fortalece em um controle difuso de convencionalidade.

Por fim, vale ressaltar que os efeitos pela incompatibilidade da norma interna em relação ao bloco de convencionalidade são: a) a invalidade da norma interna, carecendo de efeitos jurídicos, e; b) a responsabilidade do Estado pelos efeitos produzidos pela norma interna inconvencional.

\section{CONCLUSÃO}

O controle de convencionalidade é um dos grandes instrumentos para a efetividade e garantia dos direitos humanos, tanto no campo internacional como nacional. A adoção de Tratados Internacionais de Direitos Humanos como paradigma para o controle jurisdicional das leis pode ser apontado como uma das maiores ferramentas para o fortalecimento do Direito Internacional de Direitos Humanos, afinal, estaria, dentro de um ordenamento jurídico interno admitindo a importância deste ramo do Direito, além de seus efeitos, como a efetiva proteção dos Tratados Internacionais de Direitos Humanos.

Esse é o pensamento sempre defendido pela Corte Interamericana de Direitos Humanos, por meio de sua construção jurisprudencial, desenvolvendo a necessidade dos Estados respeitarem o sistema interamericano de direitos humanos através do Poder Judiciário. Todavia, esse sistema interamericano de direitos humanos não pode ser representado unicamente pela Convenção Americana de Direitos Humanos, por mais significativo que seja este instrumento, 
logo, a ideia de um bloco de convencionalidade como parâmetro de um controle jurisdicional deve ser mais desenvolvido, pois, mesmo que busque estabelecer um padrão no sistema interamericano de proteção aos direitos humanos é importante que essas mesmas garantias e proteção dos direitos humanos não podem ser “congeladas" a normas formais, mas a um conjunto jurídico cujo sua interpretação deve sempre constante ao intuito de atingir a real força normativa que os Tratados Internacional de Direitos Humanos, em seu percurso histórico, sempre necessitaram ter.

Ainda, não há como negar a possibilidade de extensão de uma nova hermenêutica que a figura do bloco de convencionalidade pode trazer dentro de um ordenamento jurídico pátrio, já que, a ideia de um paradigma amplo como a Corte Interamericana de Direitos Humanos adotou, tendo até que Estados-membros, respeitem, mesmo que de forma indireta, um Tratado Internacional de Direitos Humanos não ratificado, demonstra a nova linguagem que se busca na cultura jurídica, em um sentido universal, influenciado em um percurso histórico de violação aos direitos do homem e no afastamento da ideia de proteção a direitos individualistas e arbitrários, o direito se aproxima mais - em uma nova interpretação - ao seu papel civilizatório, humano que o mundo necessita.

\section{REFERÊNCIAS}

BENAVANTE CHORRES, Hesbert. El juez de control como garante de la convencionalidad de las normas en el nuevo proceso penal mexicano. Estudios Constitucionales. ano 10. n. 1. 2012. p. 145-200. Disponível em: http://www.scielo.cl/scielo.php?pid=S071852002012000100005\&script=sci_arttext. Acesso em: 16 jul. 2013.

CORREIA, Alexandre. SCIASCIA, Gaetano. Manual de direito romano. 5. ed. Estado da Guanabara: Série “Caderno Didáticos”. 1969.

Corte IDH. Caso Almonacid Arellano y otros Vs. Chile. Excepciones Preliminares, Fondo, Reparaciones y Costas. Sentencia de 26 de septiembre de 2006. Serie C No. 154.

http://www.corteidh.or.cr/docs/casos/articulos/seriec_154_esp.pdf. Acesso em: 16 jul. 2013.

CORTE IDH. El Derecho a la Información sobre la Asistencia Consular en el Marco de las Garantías del Debido Proceso Legal. Opinión Consultiva OC-16/99 de 1 de octubre de 1999. Serie A No. 16. http://www.corteidh.or.cr/docs/opiniones/seriea_16_esp.pdf. Acesso em: 16 jul. 2013.

CORTE IDH. Caso "La Última Tentación de Cristo“ (Olmedo Bustos y otros) Vs. Chile. Fondo, Reparaciones y Costas. Sentencia de 5 de febrero de 2001. Serie C No. 73. Disponível em: http://www.corteidh.or.cr/docs/casos/articulos/Seriec_73_esp.pdf. Acesso em: 16 jul. 2013. 
CORTE IDH. Caso Myrna Mack Chang Vs. Guatemala. Fondo, Reparaciones y Costas. Sentencia de 25 de noviembre de 2003. Serie C No. 101. Disponível em:

http://www.corteidh.or.cr/docs/casos/articulos/seriec_101_esp.pdf. Acesso em: 16 jul. 2013.

CORTE IDH. Caso Tibi Vs. Ecuador. Excepciones Preliminares, Fondo, Reparaciones y Costas. Sentencia de 7 de septiembre de 2004. Serie C No. 114. Disponível em:

http://www.corteidh.or.cr/docs/casos/articulos/seriec_114_esp.pdf. Acesso em: 16 jul. 2013.

CORTE IDH. Caso Trabajadores Cesados del Congreso (Aguado Alfaro y otros) Vs. Perú.

Excepciones Preliminares, Fondo, Reparaciones y Costas. Sentencia de 24 de Noviembre de 2006. Serie C No. 158. Disponível em:

http://www.corteidh.or.cr/docs/casos/articulos/seriec_174_esp.pdf. Acesso em: 16 jul. 2013.

CORTE IDH. Caso Ibsen Cárdenas e Ibsen Peña Vs. Bolivia. Fondo, Reparaciones y Costas. Sentencia de 1 de septiembre de 2010 Serie C No. 217. Disponível em:

http://www.corteidh.or.cr/docs/casos/articulos/seriec_217_esp1.pdf. Acesso em: 16 jul. 2013.

CORTE IDH. Caso Cabrera García y Montiel Flores Vs. México. Excepción Preliminar, Fondo, Reparaciones y Costas. Sentencia de 26 de noviembre de 2010 Serie C No. 220. Disponível em: http://www.corteidh.or.cr/docs/casos/articulos/seriec_220_esp.pdf. Acesso em: 16 jul. 2013.

GOMES, Luiz Flávio. Controle de convencionalidade: Valerio Mazzuoli "versus" STF. Disponível em: http://ww3.lfg.com.br/public_html/article.php?story=20090615165108665\&mode=print. Acesso em: 01 ago. 2013.

GUERRA, Sidney. A proteção internacional dos direitos humanos no âmbito da corte interamericana e o controle de convencionalidade. Revista Nomos. v. 32.2. jul/dez. 2012. Disponível em: http://mdf.secrel.com.br/dmdocuments/Sidney\%20Guerra.pdf. Acesso em: 15 jul. 2013.

MAC-GREGOR, Eduardo Ferrer. Interpretación conforme y control difuso de convencionalidad. El nuevo paradigma para el juez mexicano. Estudios Constitucionales. ano 9. n. 2. 2011. Disponível em:

http://www.conatrib.org.mx/html/Paneles/Paneles/PanelVIII_InterpretaciónConformeControlDi fusoConvencionalidad_EduardoFerrer.pdf. Acesso em: 16 jul. 2013.

MAZZUOLI, Valerio de Oliveira. O controle jurisdicional da convencionalidade das leis. Coleção direito e ciências afins: vol. 4. São Paulo: Editora Revista dos Tribunais. 2009.

MAZZUOLI, Valerio de Oliveira. O controle jurisdicional da convencionalidade das leis: o novo modelo de controle de produção normativa doméstica sob a ótica do "diálogo das fontes". Revista Argumenta. n. 15. 2.011. p; 77-114. Disponível em: http://seer.uenp.edu.br/index.php/argumenta/article/view/200/199. Acesso em: 12 jul. 2013.

PIOVESAN, Flávia. Temas de direitos humanos. 5. ed. São Paulo: Saraiva. 2.012.

PUCCINELLI JUNIOR, André. Curso de direito constitucional. 1. ed. São Paulo: Saraiva. 2.012. 
QUINCHE RAMÍREZ, Manuel Fernando. El control de constitucionalidad y el control de convencionalidad. Revista Centro de Estudios Políticos. Disponível em:

http://www.centrodeestudiospoliticos.com/descargas/1.8.pdf. Acesso em: 16 jul. 2013.

RAMOS, André de Carvalho. Teoria geral dos direitos humanos na ordem internacional. 2. ed. São Paulo: Saraiva. 2012.

RUSSOWSKY, Iris Saraiva. O controle de convencionalidade das leis: uma análise na esfera internacional e interna. RIBD - Revista do Instituto do Direito Brasileiro. ano 1. n. 3. 2012. Disponível em: http://www.idb-fdul.com/uploaded/files/2012_03_1745_1826.pdf. Acesso em: 16 jul. 2013.

SAGÜÉS, Néstor Pedro. El “control de convencionalidad” em el sistema interamericano, y sus anticipios em el âmbito de los derechos econômicos-sociales. Concordancias y diferencias com el sistema europeo. Biblioteca jurídica virtual del instituto de investigaciones jurídicas de la UNAM. Disponível em: http://biblio.juridicas.unam.mx/libros/7/3063/16.pdf. Acesso em: 16 jul. 2013.

SAGÜÉS, Néstor Pedro. Obligaciones internacionales y control de convencionalidad. Estudios Constitucionales. ano 8. n. 1. 2010. p. 117-136. Disponível em:

http: / / www.scielo.cl/scielo.php?pid=S0718-52002010000100005\&script=sci_arttext. Acesso em: 16 jul 2013.

SALDANHA, Jânia Maria Lopes. VIEIRA, Lucas Pacheco. O controle difuso de convencionalidade das leis na justiça do trabalho com base nas convenções da organização internacional do trabalho: caminhos para a internacionalização do direito. Pensar - Revista de ciências jurídicas. v. 15. n. 2. 2.010. p. 457-485. Disponível em:

http://ojs.unifor.br/index.php/rpen/article/view/2136/1734. Acesso em: 12 jul. 2013.

Recebido em: 27.09.2013

Aprovado em: 29.12 .2013 